Acta vet. scand. $1967,8,347-359$.

From the Department of General Pathology and Pathological Anatomy, Royal Veterinary and Agricultural College, Copenhagen, Denmark.

\title{
GASTRITIS \\ IN SOWS DUE TO HYOSTRONGYLUS RUBIDUS - IN ONE CASE ASSOCIATED WITH BALANTIDIUM COLI
}

By

Steen Larsen

Gastric lesions in swine associated with the red stomach worm, Hyostrongylus rubidus, have been reported from several European countries, the USSR, the USA, New Zealand and Australia (5, 6, $9,11,16,19,21,22,25,29,30,32)$. Recently, the first description of the presence of this parasite in Danish sows was given by Dunn \& Jacobs (13) and by Jacobs (17). He recorded the incidence of $H$. rubidus among sows from the island of Zealand as approximately $11 \%$. About the same time 3 cases of gastritis in sows due to $H$. rubidus were diagnosed by the present author. Since this disease has not previously been reported from the Scandinavian countries, a brief account is given of the abovementioned cases.

\section{MATERIAL}

Four sows of Danish landrace, all approx. 3 years old, from a farm in North Zealand were admitted to the Medical Clinic of this college with a history of weight loss during several months in all adult swine of the herd. The owner stated that, as a general procedure, all sows were placed in a small outdoor pen after breeding and were taken inside immediately before farrowing. No diarrhea but occasional vomitus had been observed in the 
affected animals. The appetite had, as a rule, been good. One of the 4 sows recovered during the stay in the clinic, the other 3 were euthanized because of emaciation and debilitation.

\section{Case 1}

\section{OBSERVATIONS}

History. Gradual loss of appetite and body weight. In the late stage of the disease the animal neither ate nor drank. It developed uremia (BUN: $118 \mathrm{mg} \%$ ), became lethargic and totally refused to move or stand up. Trichostrongylid eggs were demonstrated in the feces by flotation test. The formolgel test was negative and the serum protein level normal $(7.6 \mathrm{~g} \%)$.

Necropsy findings. The carcass weighed $76 \mathrm{~kg}$. The animal was extremely emaciated with the bones protruding everywhere under the skin. The mucous membranes were pale and the sparse subcutaneous and intermuscular connective tissue was dry. There was a slight, diffuse granular thickening of the gastric mucosa and the stomach wall felt somewhat firmer and less pliable than normal. Immediately upon opening of the stomach and intestines a distinct smell of ammonia from their mucosal surfaces could be perceived. The renal cortices were slightly paler than normal but the kidneys were otherwise of normal appearance.

Additional findings included a mild, acute sero-fibrinous pericarditis, dilatation of the heart, edema of the lungs and acute passive congestion of the liver.

Microscopic findings. The lesions in the stomach were confined to the mucosa. Embedded in slightly dilated gastric glands with markedly attenuated epithelium fragments of cuticle-covered helminth larvae, approx. $30 \mu$ in diameter, were present. Similar larvae were also found in a dilated gastric pit and embedded in mucus and desquamated epithelial cells on the mucosal surface. Six larvae were counted in a $2.5 \mathrm{~cm}$ long section of the fundus. In the lamina propria there was a patchy infiltration with lymphocytes and histiocytic cells generally corresponding to and surrounding the location of the parasites. A final identification of the parasites was not possible, but the presumptive diagnosis of Hyostrongylus rubidus was made.

In the kidneys there was hydropic degeneration of the convoluted tubules, the cells of which were markedly swollen with foamy, ballooning cytoplasm and had moderately shrunken nuclei. 


\section{Case 2}

History. The animal was extremely emaciated and somewhat lethargic but had a fairly good appetite upon admission to the clinic. Multiple bite wounds were present on the head, neck and trunk. There was anemia with $42 \%$ hemoglobin (Sicca). The temperature was in the normal range, the formolgel test was negative, the BUN was normal but the serum protein level was slightly decreased $(5.9 \mathrm{~g} \%)$. Trichostrongylid eggs were demonstrated in the feces.

Necropsy findings. The carcass weighed $74 \mathrm{~kg}$ and displayed the same degree of emaciation as the animal in case 1 . The mucous membranes were pale and the skin was dry and scaly with numerous crust-covered erosions and multiple, chronically infected and granulating wounds especially on the neck and head. The distal two thirds of the right ear flap were missing leaving an irregular free edge of partly crust-covered, suppurating granulation tissue. A moderate generalized edema of the subcutaneous and intermuscular tissue was present. There were recent fractures of the right 7 th and 8 th rib with an abscess in one of the fracture sites.

The stomach wall was markedly thickened and the mucosal surface, except for the immediate vicinity of the cardia and the pylorus, was covered with clear tenacious mucus and up to $1 \mathrm{~cm}$ thick, yellowish, semi-dry, crumbly, pseudomembraneous masses of necrotic tissue which gave the surface a corrugated and verrucose appearance (Fig. 1 ). These masses could be easily removed leaving grayish-red, coalescent ulcerated areas beneath them. On the surface of and buried in the necrotic tissue there were innumerable, extremely thin, reddish-brown worms measuring from about 5 to $8 \mathrm{~mm}$ in length (Fig. 2). They were identified as Hyostrongylus rubidus. A more moderate number of the same worms were present in the intestinal contents as far back as in the colon but the intestines themselves exhibited no gross changes. There was hyperplasia of the gastric lymph nodes.

The right pleural cavity contained approx. 1.51 of serous, purulent and fibrinous exudate and there were fibrinous adhesions between the visceral and parietal pleura, especially corresponding to the previously mentioned costal fracture sites. There was verminous bronchitis and bronchopneumonia with the presence of pus and entangled masses of thready lungworms, identified as Metastrongylus apri, in the lumen of the bronchi 
and bronchial branches and several ill-defined, consolidated and partly hemorrhagic areas in the right diaphragmatic lobe.

The stomach was examined bacteriologically, but no pathogenic bacteria were found.

Microscopic findings. The essential microscopic lesion of the stomach was that of a diphtheroid gastritis though varying somewhat in severity and duration from one area to the other. There was mucinous hypersecretion, fibrinous exudation and necrosis of the mucosa which was infiltrated with and demarcated by large numbers of neutrophilic granulocytes. In some areas up to 3 distinct lines of demarcation (linear accumulations of nuclear debris) were observed, one above the other, indicating fluctuations in the progression of the lesion. Below the level of demarcation many gastric glands were dilated with hyperplasia, attenuation or marked atrophy of their epithelial lining. Embedded in the mucus and necrotic tissue and also lying deeply in several of the dilated glands were numerous adult Hyostrongylus rubidus and strongylid eggs containing from 4 to approx. 16 cells. A number of the worms were gravid females with eggs in the uterus. In 2 instances erythrocytes were observed filling the intestinal lumen of the worms. In addition to the Hyostrongylus spp., and in the same locations, large numbers of Balantidium coli were present, in some areas with a conspicuous predominance of the latter. This was especially the case in the most severely and chronically affected parts of the stomach. In these areas there was necrosis of almost the entire gastric mucosa. Only the bottom part of a few scattered glands was relatively intact, the rest of the mucosa had the appearance of a chronically inflamed tissue in which a few atrophic remnants of glandular epithelium were seen among neutrophilic granulocytes, lymphocytes, plasma cells, histiocytes, proliferated blood vessels and, particularly in the deeper layer of the mucosa, collagenous connective tissue hyperplasia. The proliferative inflammatory changes continued into the submucosa and extended down into the muscularis along the vascular interstitium. While in these areas the exudate and necrotic masses still contained large numbers of both $H$. rubidus, strongylid eggs and $\mathrm{B}$. coli, the latter were especially numerous in the deeper zones of the mucosa, i. e. in the dilated remnants of the gastric glands (Fig. 3) or sometimes in direct contact with the underlying, but viable, tissue. The microscopic appearance of the nonnecrotic areas of the gastric mucosa was somewhat similar to the 
picture seen in case 1. The changes consisted of infiltration in the lamina propria with lymphocytes, histiocytic cells and some plasma cells and a mild increase in its basal portion of collagenous connective tissue. Here and there on the mucosal surface or lodged in the openings of some gastric pits a few Balantidium spp. were present. In one instance a larva, approx. $25 \mu$ in diameter and identical in appearance to those seen in case 1, was observed in the lumen of a gastric gland. The average diameter of the adult Hyostrongylus spp. as seen in tissue sections was $80 \mu$. The varying degrees of inflammatory changes, with or without necrosis, merged gradually into one another in the different areas of the stomach and, as a rule, the more severe the lesions the larger was the number of parasites present - both $\mathrm{H}$. rubidus and $\mathrm{B}$. coli.

The gastric lymph nodes exhibited diffuse hyperplasia of the lymphoid tissue and prominent patchy accumulations of neutrophilic granulocytes in the sinuses.

In the liver there was activation of the sinusoidal retothelium (Kupffer cells) with hemosiderin deposits confined to the peripheral zones of the acini.

Corresponding with the macroscopic changes, the lesions in the lungs consisted of lobular bronchitis, bronchiolitis and peribronchitis with masses of neutrophilic granulocytes, desquamated bronchial epithelial cells and several lungworms filling the lumen of the bronchi and bronchioles and extension of the exudate through the bronchial wall into the peribronchial tissue and alveoli. In the adjacent tissue there was prominent interstitial and subpleural edema and in the alveoli, desquamation of septal cells, edema, emphysema or atelectasis and varying amounts of fibrin and extravassated erythrocytes. The pleura was the seat of a subacute purulent inflammation.

No significant lesions were observed in the jejunum, cecum, colon, mesenteric lymph nodes, spleen or kidneys, nor were Balantidium spp. or other parasites observed during the microscopic examination of the intestinal tract.

\section{Case 3}

History. The sow was markedly emaciated but its appetite was fairly good and the animal's general attitude was not significantly altered. A slight weight gain was noted during the stay in the clinic. There was also an episode of diarrhea during the stay. The sow was anemic with a hemoglobin $\%$ of 36 (Sicca). 
Other laboratory findings included: negative formolgel test, normal BUN and a serum protein level in the low normal range $(6.2 \mathrm{~g} \%)$. The body temperature was normal. ${ }^{131}$-albumin turnover was studied in this sow and in the animal which recovered clinically. In both cases the turnover data were essentially normal (Nielsert, 23).

Necropsy findings. The carcass weighed $84 \mathrm{~kg}$ and exhibited emaciation comparable with that of the previous cases. The skin was dry and scaly and the mucous membranes were pale. There was a moderate generalized subcutaneous and intermuscular edema. The pericardial sac contained approx. $100 \mathrm{ml}$ of serous fluid.

Tenacious glassy mucus covered the gastric mucosa which was prominently and diffusely thickened and had a coarsely granular surface (Fig. 4). Embedded in the mucus and evenly distributed over the entire mucosal surface were numerous tiny, reddish-brown worms, $5-\mathbf{- 8} \mathrm{mm}$ in length. In number and appearance they were similar to those found in case 2 . They were likewise identified as $\mathrm{H}$. rubidus. There was hyperplasia of the gastric and mesenteric lymph nodes.

Microscopic findings. The changes in the stomach were very similar to those observed in case 1 . In addition to the presence of adult Hyostrongylus spp. on the mucosal surface some of the gastric glands contained larvae identical with the ones previously described. Their number and distribution in the mucosa appeared to be the same as in case 1 . Several glands were moderately dilated and displayed varying degrees of hyperplasia with folding and projection of the glandular epithelium into the lumen. The epithelium surrounding the buried larvae was attenuated but intact. In the lamina propria there was a more or less diffuse mesenchymal reaction consisting of an increased amount of fine collagenous fibers and a hypercellularity due to fibroblasts, lymphocytes, plasma cells and eosinophilic granulocytes. This mesenchymal reaction was most pronounced in the superficial portion of the mucosa. No lesions were noted in the other layers of the stomach.

Mild hyperplastic changes in the lamina propria with diffuse lympho-histiocytic infiltrations and a conspicuous eosinophilia were present in the jejunum and, to a lesser extent, in the cecum and colon. No parasites were found. 
In the gastric lymph nodes there was hyperplasia of the lymphoid tissue and collagenization of the nodal reticulum. The same changes were present in the mesenteric nodes with the addition of small accumulations of neutrophilic granulocytes and 2 granulomas of parasitic origin with unidentifiable remnants of the parasite (larva) in the center of one of them.

There was hyperplasia of the lymphoid follicles in the spleen but no significant lesions in the liver, kidneys or lungs.

\section{DISCUSSION}

Although a final identification of the parasites in case 1 could not be made, it seems safe to assume, in view of their close resemblance to those seen in the other cases, that they too represented larvae of $\mathrm{H}$. rubidus. Worms were not observed during the gross examination of the stomach in case 1 . However, the clinical demonstration of trichostrongylid eggs in the animal's feces and the absence, in the gastrointestinal tract, of other parasites which might have produced these eggs suggest that adult Hyostrongylus spp. indeed have been present but that their presence, owing to their extremely small size, has been overlooked especially since parasitism of the stomach was not suspected at that time.

The symptomatology and environmental circumstances in the present outbreak concur with the commonly observed features of spontaneous hyostrongylosis in swine (cf. Jacobs, 17). Similarly, the predominant occurrence in breeding sows of this disease is emphasized by most authors $(5,7,11,17,21,25,29)$ although enzootics among young pigs also have been reported $(6,9,30)$. However, with regard to the pathogenicity of $H$. rubidus there has been some discrepancy of opinions.

Hassall \& Stiles (15), who originally described the worm, found extensive gastric ulceration in a number of pigs containing the parasites but this was not a constant finding. They thought the worms to have scarcely any clinical importance and did not even feel justified in considering them as the cause of ulceration. Porter (26) observed, in experimental infections, gastric lesions varying from slight erosions and hyperemia to definitely eroded areas or ulcers in the mucosa but found no clinical evidence of injury to the host by the worms. Stomach lesions ascribed to the presence of $\mathrm{H}$. rubidus have been reported by other workers as: mucosal thickening, diphtheresis $(5,21)$; mucosal thickening, hemorrhage, erosions, diphtheresis (6); fibrinous-diphtheroid 
gastritis $(9,32)$; ulceration $(11,29)$; diphtheresis $(22)$; diphtheresis or chronic gastritis (25) and necrotizing gastritis (30). Hoogland \& Seijffers (16) described hyperplastic gastritis with occasional hemorrhagic erosions as the essential lesions in their 18 cases. In 3 of these cases they also found varying degrees of diphtheresis but did not believe this to be caused primarily by the worms.

A few writers specifically associated changes in the stomach with the histotropic phase of $\mathrm{H}$. rubidus larvae. Thus, Davidson (10) stated that some of the lesions resulted from the coalescence of nodules caused by the immature $H$. rubidus, and similar findings were reported by Kotlán (19). In experimentally infected guinea pigs Alicata (1) found that ulceration and hemorrhages were caused by the larvae developing to maturity in the gastric mucosa.

The current conception, already advanced by some earlier workers $(5,9)$, seems to be that $H$. rubidus is only a potentially pathogenic parasite and that the degree of clinical disease as well as of patho-anatomical changes in the stomach will depend primarily on an upset host-parasite balance with lowered resistance in the host and only secondarily on the number of worms present (cf. Jacobs, 17). Thus, the frequent occurrence of hyostrongylosis in breeding sows is explained as being triggered by the strain of lactation, an idea supported by the observation of a parturient rise in the number of Oesophagostomum and $\mathrm{H}$. rubidus eggs in the feces of infested animals and a close association between lactation and the maintenance of this rise (8).

All 3 animals in the present cases exhibited hyperplastic gastritis, considered to be at least partly due to the presence of $H$. rubidus larvae in the gastric glands. Since the number of adult Hyostrongylus spp. was roughly the same in case 2 and 3, lowered resistance in case 2, because of the concomitant lungworm infestation and the multiple infected wounds, could serve to explain the severe diphtheresis superimposed on the hyperplastic changes in the stomach of this animal. This, however, leaves the question of the importance of B. coli.

Although Almejew $(2,3)$ considered some forms of B. coli to be primarily pathogenic for swine giving rise to hemorrhagicnecrotizing inflammation in the cecum and colon, the consensus of opinion seems to be that this parasite, being a natural inhabitant of the large intestine of swine, is of limited pathogenicity 


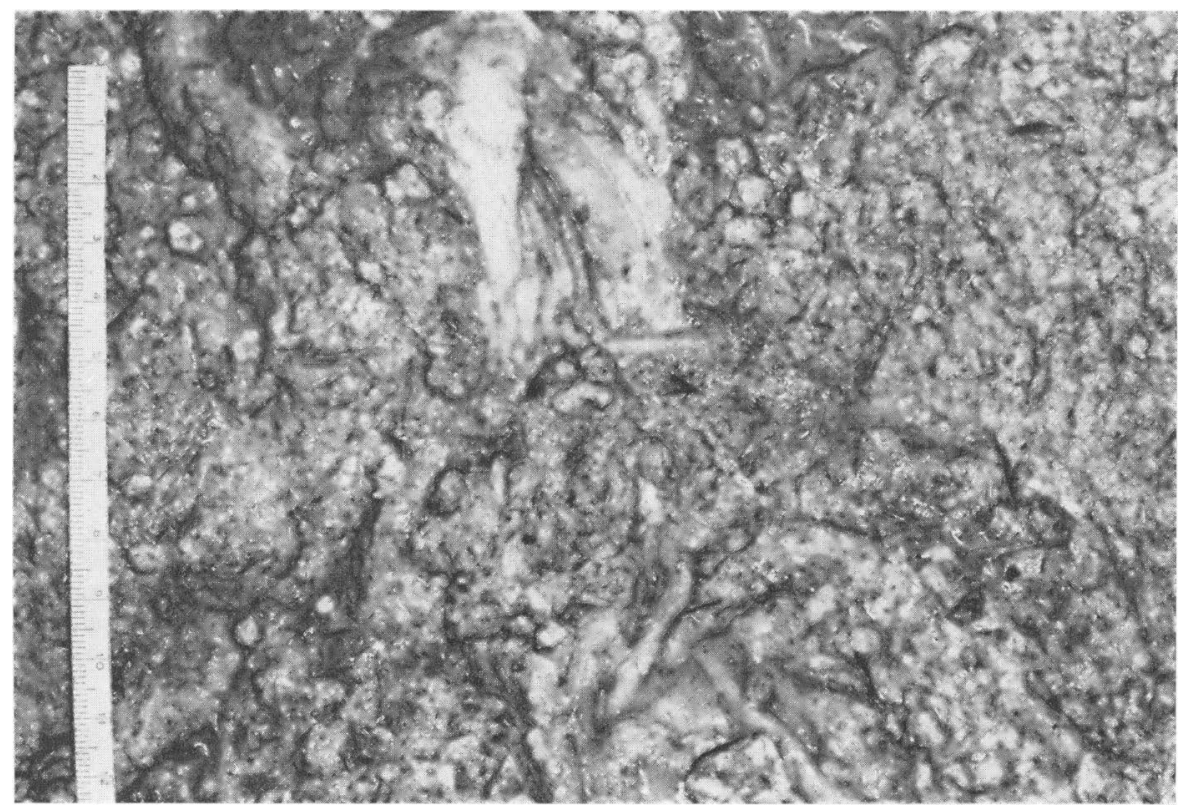

F i g u r e 1. Stomach from case 2. Cardia at top center. Corrugated, verrucose appearance of mucosal surface due to masses of exudate and necrotic tissue.

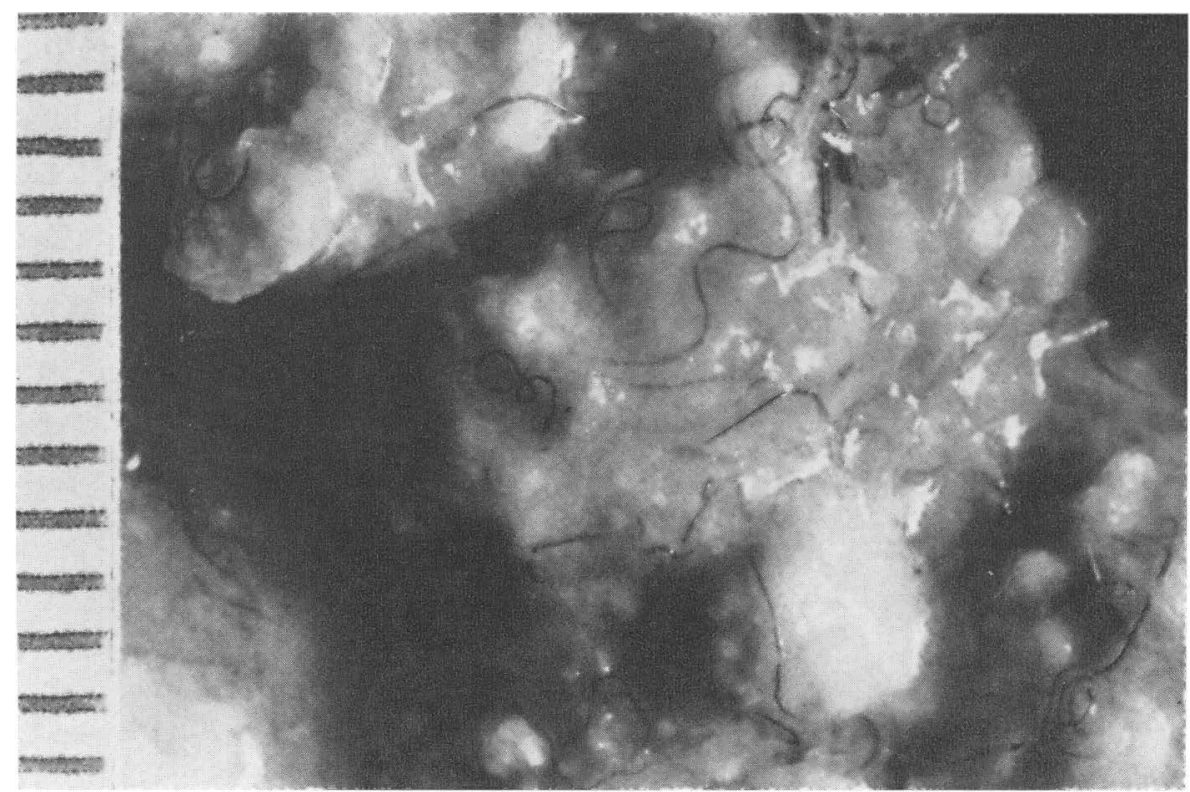

Fig u re 2. Close view of stomach from case 2. Many Hyostrongylus spp. partly buried in mucus and pseudomembraneous masses. Scale at left indicates millimeters. 


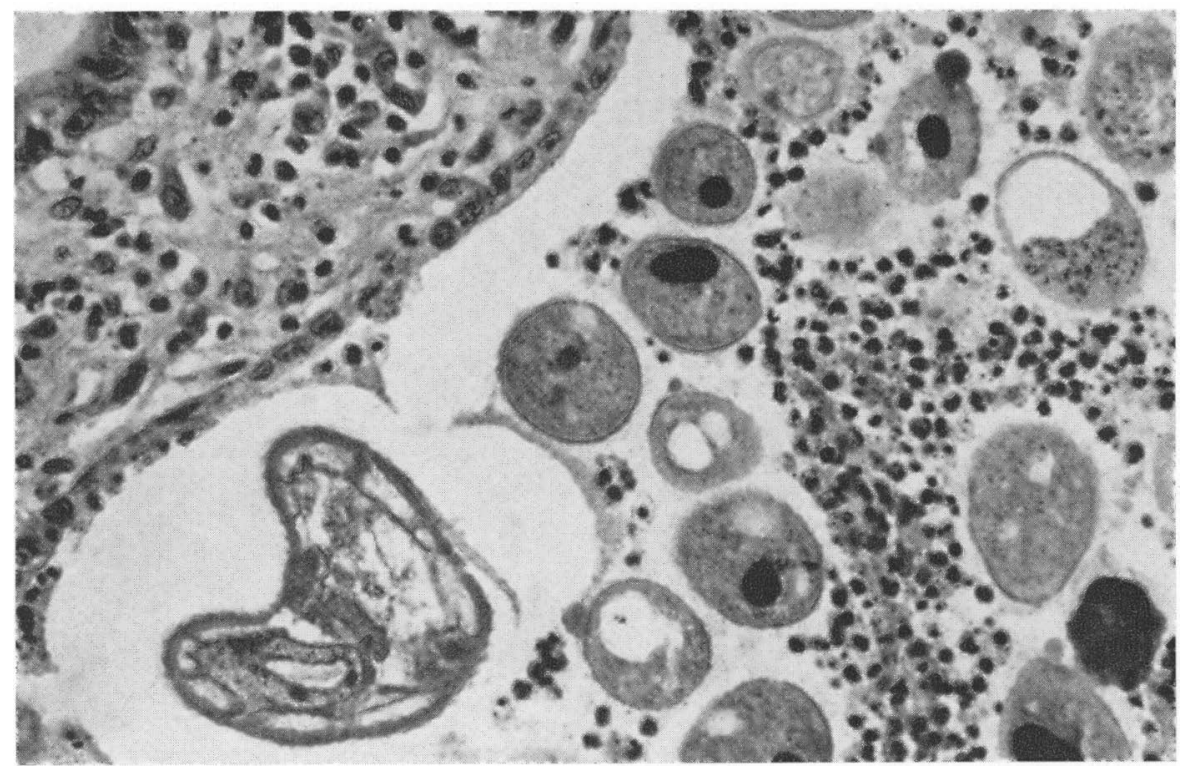

$\mathrm{F}$ i g u r e 3. Section of stomach from case 2. A single adult $\mathrm{H}$. rubidus in cross section, several Balantidium spp. and cellular debris in dilated gastric gland with attenuated epithelial lining. Cellular infiltration and mild connective tissue hyperplasia in lamina propria at upper left. $\mathrm{H} \& \mathrm{E} . \times 320$.

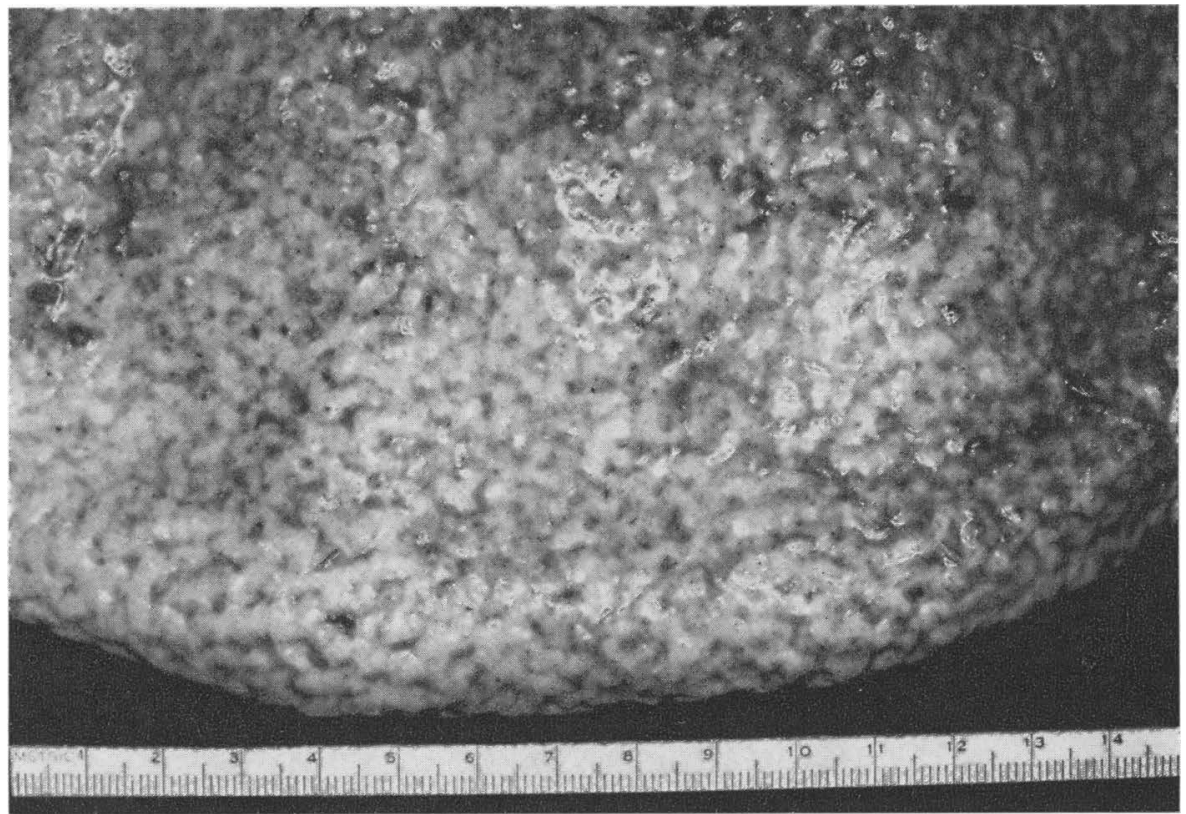

Figure 4. Stomach from case 3. Diffuse thickening and coarse granulation of mucosal surface. 
and only a secondary invader in the course of some other enteric disease $(12,18,20,27,31)$. Usually associated with lesions in the cecum and colon it has, however, also been found in the small intestine in connection with enteritis. (18). To the author's knowledge it has not previously been reported in association with gastritis.

Gastric achylia frequently accompanies diffuse gastritis in man (4) and in ostertagiasis in cattle abomasal hypochlorhydria has been demonstrated $(24,28)$. In the present cases gastritis due to $H$. rubidus may, in the same manner, have created an environment of sufficiently low acidity for ingested cysts or trophozoites of $B$. coli to live and multiply in the stomach, thus accounting for their presence in case 2. Their participation, if any, in the development of the gastric diphtheresis in this case is impossible to ascertain, partly because their location in the tissue coincided with that of $H$. rubidus, and partly because the lesions were esisentially similar to those described by other workers in cases of "pure" hyostrongylosis.

Davidson (10) compared the hyperplastic changes of the stomach in hyostrongylosis in swine with the abomasal hyperplasia of ostertagiasis in cattle and stated that these two infections were very similar in many respects. On the same occasion Connan (7), discussing the emaciation which is a consistent feature of hyostrongylosis, suggested that the gastritis due to $H$. rubidus might cause the same sort of upset in digestion of protein as is found in ostertagiasis.

In this context it should be mentioned that despite morphological similarities between the gastric and abomasal hyperplasia in the two conditions, important pathophysiological differences seem to exist. Thus, in hyperplastic abomasitis chronic diarrhea is the most prominent clinical symptom, but although some authors $(5,11)$ do mention the occurrence of diarrhea in hyostrongylosis, others $(6,10,21,29)$ describe this as being uncommon which is in keeping with the observation that diarrhea was not a feature of the disease in the present outbreak. Shanks (29) states that if diarrhea does occur in hyostrongylosis, it is probably caused by some other agent. Studies by Nielsen (24) of serum protein metabolism in cattle with verminous hyperplastic abomasitis (and other chronic diarrheal diseases) by means of I131_ labelled albumin and I ${ }^{125}$-labelled immunoglobulin have demonstrated marked hypercatabolism with increased turnover rates 
of the injected substances during the diarrheal phases of the disease due to loss of protein via the gastrointestinal tract. The results of similar studies by the same author (23) in 2 sows with hyostrongylosis, including case 3 in the present report, did not indicate gastrointestinal protein loss, since the albumin turnover rates, as previously mentioned, were essentially normal. These findings suggest that the emaciation seen in swine with hyostrongylosis is mainly due to a deficient gastric digestion.

The finding of erythrocytes in the intestinal lumen of 2 adult Hyostrongylus spp. in case 2 supports the claim that this parasite is a bloodsucker $(14,18)$. However, whether this quality alone suffices to explain the severe anemia commonly associated with hyostrongylosis is not clear.

\section{ACKNOWLEDGMENTS}

The author's thanks are due to the Department of Hygiene and Bacteriology, Royal Veterinary and Agricultural College, for carrying out the bacteriological examination of material from case 2 and to amanuensis, cand. mag. J. A. Guildal, of the same department, for the final identification of the parasites found in cases 2 and 3.

\section{REFERENCES}

1. Alicata, J. E.: Early developmental stages of nematodes occurring in swine. Tech. Bull. U. S. Dept. Agric. 1935, 489, 1-96.

2. Almejew, C.: Über die durch Balantidien hervorgerufene Dysenterie bei Schweinen. Mh. Vet.-Med. 1962, 17, 619-622.

3. Almejew, C.: Zur Frage der Ausbreitung von Balantidien im Darm der Schweine. Mh. Vet.-Med. 1963, 18, 250.

4. Boyd, W.: A Textbook of Pathology. Structure and Function in Diseases. 7th Ed., Lea \& Febiger, Philadelphia 1961.

5. Castle, A. F.: Some clinical notes on pig diseases. Verminous gastritis in sows. Vet. J. 1932, 88, 474-475.

6. Clay, A. L.: A note on the prevalence and pathogenic importance of Hyostrongylus rubidus in pigs in North Queensland. Aust. vet. J. 1938, 14, 194-196.

7. Connan, R. M. in discussion to Taffs, L. F.: Helminths in the pig. Vet. Rec. 1966, 79, 671-693.

8. Connan, R. M.: Observations on the epidemiology of parasitic gastro-enteritis due to Oesophagostomum spp. and Hyostrongylus rubidus in the pig. Vet. Rec. 1967, 80, 424-429.

9. Crocker, W. J.\& H. E. Biester: Strongylus rubidus as an etiological factor in gastric lesions of hogs. J. Amer. vet. med. Ass. 1920, $57,527-538$. 
10. Davidson, J. B. in discussion to Taffs, L. F.: Helminths in the pig. Vet. Rec. 1966, 79, 671-693.

11. Dodd, D. C.: Hyostrongylosis and gastric ulceration in the pig. N. Z. vet. J. $1960,8,100-103$.

12. Dunlap, J. S.: Protozoa. In, H. W. Dunne (ed.) : Diseases of Swine. 2nd Ed., Iowa State Univ. Press, Ames 1964, 557-572.

13. Dunn, A. M. \& D. E. Jacobs: Records of pig helminths in Great Britain and Denmark. Vet. Rec. 1966, 79, 156.

14. Euzeby, J.: Les Maladies Vermineuses des Animaux Domestiques et Leurs Incidences sur la Pathologic Humaine. Tome premier, Fasc. deux., Vigot Frères, Paris 1963.

15. Hassall, A. \& C. W. Stiles: Strongylus rubidus, a new species of nematode parasitic in pigs. J. comp. Med. vet. Arch. 1892, 13, 207-209.

16. Hoogland, H. J. M. \& S. M. Seijfers: Maagwormziekte (Hyostrongylosis) bij het varken. T. Diergeneesk. 1928, 55, 377-386.

17. Jacobs, D. E.: Forekomsten af svinets maveorm, Hyostrongylus rubidus, i Danmark. Medlemsbl. danske Dyrlægeforen. 1966, 49, 509-516.

18. Jubb, K. V. F. \& P. C. Kennedy: Pathology of Domestic Animals. Vol. 2, Academic Press, New York/London 1963.

19. Kotlán, A.: On the histotropic phase of the parasitic larvae of Hyostrongylus rubidus. Acta vet. Acad. Sci. hung. 1949, 1, $76-82$.

20. Levine, N. D.: Protozoan Parasites of Domestic Animals and of Man. Burgess, Minneapolis 1961.

21. Nicolson, T. B. \& J. G. Gordon: An outbreak of helminthiasis associated with Hyostrongylus rubidus. Vet. Rec. 1959, 71, 133.

22. Nieberle, $K$. \& P. Cohrs: Lehrbuch der speziellen pathologischen Anatomie der Haustiere. 4. Aufl., Fischer, Jena 1961.

23. Nielsen, $K$.: Metabolism and distribution of I131-labelled albumin in pigs with gastrointestinal diseases. Acta vet. scand. 1966, 7, $321-329$.

24. Nielsen, K.: Gastrointestinal Protein Loss in Cattle. A Clinical and Pathophysiological Study. Mortensen, Copenhagen 1966.

25. Oppermann, T.: Eine durch Strongylus rubidus bedingte Massenerkrankung bei Zuchtsäuen in Deutschland. Dtsch. tierärztl. Wschr. 1905, 13, 469-472.

26. Porter, D. A.: Experimental infections of swine with the red stomach worm, Hyostrongylus rubidus. Proc. helminth. Soc. Wash. 1940, 7, 20-27.

27. Richardson, U. F. \& S. B. Kendall: Veterinary Protozoology. 3rd Ed., Oliver \& Boyd, Edinburgh/London 1963.

28. Ross, J. G., J. R. Todd \& C. Dow: Ostertagiasis in cattle. Vet. Rec. 1963, 75, 954. 
29. Shanks, P. L.: Some observations on Hyostrongylus rubidus in sows and its treatment with various anthelmintics. N. Z. vet. J. $1965,13,38-40$.

30. Skrjabin, K. J. \& P. W. Bekensky: Wurmenzootie der Schweine, verursacht durch Hyostrongylus rubidus in Russland. Berl. tierärztl. Wschr. 1925, 41, 52-53.

31. Smith, H. A. \& T. C. Jones: Veterinary Pathology. 3rd Ed., Lea \& Febiger, Philadelphia 1966.

32. Supperer, R.: Die Parasiten der Schweine - Diagnose, Pathogenität, volkwirthschaftliche Bedeutung, Bekämpfung. Wien. tierärztl. Mschr. 1955, 42, 215—235.

\section{SUMMARY}

Three cases of gastritis in sows due to the stomach worm Hyostrongylus rubidus are described. This disease has not previously been reported from the Scandinavian countries.

Diffuse gastritis and extreme emaciation were the essential findings at necropsy in all 3 cases.

In 2 animals the gastric changes consisted of diffuse nodular hyperplasia of the mucosa. In the third case similar hyperplastic changes were present, but these were largely obscured by a superimposed extensive diphtheresis of the mucosa.

The gastric changes in cases of hyostrongylosis reported in the literature and the conceptions regarding their pathogenesis are reviewed and discussed.

In the sow with diphtheroid gastritis large numbers of Balantidium coli, in addition to $H$. rubidus, were present in the altered stomach mucosa. It is assumed that the gastritis due to $\mathrm{H}$. rubidus has resulted in gastric hypochlorhydria thus creating an environment of sufficiently low acidity for ingested Balantidium spp. to live and multiply. Whether this parasite has participated in the development of the gastric diphtheresis is impossible to ascertain.

\section{ZUSAMMENFASSUNG}

Gastritis bei Säuen hervorgerufen von Hyostrongylus rubidus. In einem Fall kombiniert mit Balantidium coli.

Drei Fälle von Gastritis bei Säuen verursacht von dem Magenwurm Hyostrongylus rubidus werden beschrieben. Dieses Leiden ist nicht früher in den skandinavischen Ländern beschrieben worden.

In allen drei Fällen waren die wesentlichsten Sektionsbefunde diffuse Gastritis und extremes Abmagern.

Bei zwei von den Tieren bestanden die Ventrikelveränderungen aus einer diffusen nodularen Schleimhauthyperplasie. In dem dritten Fall wurden ähnliche hyperplastische Veränderungen nachgewiesen, meistens doch von einer verbreiteten diphteroiden Entzündung in der Schleimhaut verwischt. 
Die in der Literatur beschriebenen Ventrikelveränderungen bei Hyostrongylose sowie die Standpunkte betreffend die Pathogenese werden durchgegangen und diskutiert.

Bei der Sau mit diphteroider Gastritis wurden in der veränderten Ventrikelschleimhaut ausser $H$. rubidus Balantidium coli in grosser Zahl gefunden. Es wird angenommen, dass die von $\mathrm{H}$. rubidus hervorgerufene Gastritis eine Hypochlorhydrie verursacht hat, wodurch ein Milieu mit genügend niedrigem Säuregrad geschaffen wurde, dass die aufgenommenen Balantidien leben und sich vermehren konnten. Wieweit dieser Parasit bei der Entwicklung der diphteroiden Entzündungsveränderungen eine Rolle gespielt hat lässt sich nicht entscheiden.

\section{SAMMENDRAG}

Gastritis hos sфer forårsaget af Hyostrongylus rubidus. - I ét tilfælde $i$ forbindelse med Balantidium coli.

Tre tilfælde af gastritis hos søer forårsaget af maveormen Hyostrongylus rubidus beskrives. Denne lidelse er ikke tidligere beskrevet fra de skandinaviske lande.

De væsentlige sektionsfund var i alle 3 tilfælde diffus gastritis og extrem afmagring.

Hos 2 af dyrene udgjordes ventrikelforandringerne af en diffus nodulær slimhindehyperplasi. I det tredje tilfælde fandtes lignende hyperplastiske forandringer, for det meste dog udviskede af en udbredt diphteroid betændelse i slimhinden.

De i litteraturen beskrevne ventrikelforandringer ved hyostrongylose og synspunkterne vedrørende deres patogenese gennemgås og diskuteres.

Hos soen med diphteroid gastritis fandtes, foruden $H$. rubidus, Balantidium coli $i$ et stort antal $i$ den forandrede ventrikelslimhinde. Det antages, at den af $\mathrm{H}$. rubidus forårsagede gastritis har medf $\varnothing \mathrm{rt}$ hypochlorhydri og derved skabt et milieu af tilstrækkelig lav surhedsgrad til at optagne Balantidier har kunnet leve og formere sig. Hvorvidt denne parasit har spillet nogen rolle for udviklingen af de diphteroide betændelsesforandringer, kan ikke afg $\varnothing$ res.

(Received July 31, 1967). 